\title{
In silico analysis for identification of tick phagotopes selected by phage-displayed libraries
}

\author{
Análises in sílico na identificação de fagotopos de carrapatos selecionados por bibliotecas de phage display \\ Carlos Roberto Prudencio ${ }^{1 *}$; Rafael Nascimento ${ }^{1}$; Moacir Marchiori Filho²; Andrea de Oliveira Marques Marra²; \\ Guilherme Rocha Lino de Souza ${ }^{3}$; Juliana Franco Almeida ${ }^{1}$; Rone Cardoso ${ }^{1}$; Matias Pablo Juan Szabót ${ }^{4}$ Luiz Ricardo Goulart $^{1}$ \\ ${ }^{1}$ Laboratório de Bionanotecnologia, Instituto de Genética e Bioquímica, Universidade Federal de Uberlândia - UFU \\ ${ }^{2}$ Vallée S/A., São Paulo - SP, Brasil \\ ${ }^{3}$ Departamento de Produção Vegetal Alto Universitário, Centro Agropecuário - CCA, Universidade Federal do Espírito Santo - UFES \\ ${ }^{4}$ Faculdade de Medicina Veterinária, Universidade Federal de Uberlândia - UFU
}

Received May 31, 2008

Accepted February 27, 2009

\begin{abstract}
Phage display techniques have been widely employed to map epitope structures which have served as the basis for developing molecular vaccines. We have applied this technique to map specific epitopes of Rhipicephalus (Boophilus) microplus. In the present study, we have identified the potential immunogens using a process in which the selected phage clones were analyzed through bioinformatics, prior to final field tests. The present study demonstrates the feasibility of identifying important $R$. (B.) microplus phagotopes for vaccine development through screening of phage-displayed random peptide libraries and bioinformatics tools.
\end{abstract}

Keywords: bioinformatics, phagotopes, phage display, tick, vaccines.

\section{Resumo}

Técnicas de phage display têm sido amplamente empregadas para o mapeamento de epítopos os quais tem servido como base para o desenvolvimento de vacinas moleculares. Esta técnica foi aplicada no mapeamento de epítopos do Rhipicephalus (Boophilus) microplus. Neste estudo, potenciais imunógenos foram identificados pela adoçáo de um processo em que os clones de fagos foram analisados por bioinformática, previamente à realizaçáo dos testes. Os resultados demonstraram a possibilidade da identificação de importantes mimetopos do $R$. (B.) microplus para o desenvolvimento de vacinas através da seleção de bibliotecas de phage display associada à análise de bioinformática.

Palavras-chave: bioinformática, fagotopos, phage display, carrapatos, vacinas.

\section{Introduction}

The need for high-throughput bioinformatic methods to characterize gene function is being driven by the generation of sequences at a rate far beyond our ability to carry out experimental functional analyses. An important clue to discovering gene function is the identification of binding partners. Phage display technology is a widely used tool for identifying either protein- or small molecule-binding (MANDAVA, 2004). This methodology is now well established as an important experimental approach in designing new reagents for diagnosis of diseases and development of novel vaccines (WANG, 2007).

This technique has been widely employed to map epitope structures which have served as the basis for developing molecular

\footnotetext{
*Corresponding author: Carlos Roberto Prudencio
}

Laboratório de Genética Molecular, Instituto de Genética e Bioquímica,

Universidade Federal de Uberlândia - UFU, Campus Umuarama, Bloco 2E, Sala 24,

CEP 38400-902 Uberlândia - MG, Brasil; e-mail: crprudencio@gmail.com

Supported by: FINEP, CNPq, CAPES, Vallée S/A, ImunoScan. vaccines. The use of peptide epitope mimics (i.e., phagotopes or mimotopes) as vaccines has become a promising strategy. The peptide epitopes may serve as useful tools for the development of effective vaccines for the design of recombinant multi-epitope antigens, peptide-based antigens, or peptide-displaying phages themselves used for immunization (BENHAR, 2001; IRVING, 2001).

We tested six phage-displayed random peptides that were selected with seven different strategies and different stringency conditions against the purified hyperimmune serum of chickens $(\operatorname{IgY})$ immunized with total proteins of larvae and adults of $R$. (B.) microplus (unpublished data). In the present study, we have applied this technique to map specific motifs of the tick $R$. (B.) microplus and to validate the peptides as potential immunogens. We adopted a multi-process of similarity analysis between the recombinant peptides and proteins of $R$. (B.) microplus deposited in the GenBank. 


\section{Material and Methods}

Peptide sequences obtained by phage DNA sequencing were analyzed with available bioinformatics programs (http://relic.bio.anl.gov/programs.aspx). FASTAskan was used to rank the proteins in descending order such that the proteins most likely to bind to a ligand would be clustered at the top. Scores were generated by calculating the similarity between each peptide sequence as compared to the length of the protein sequence of the $R$. (B.) microplus. The similarity threshold was selected both empirically and experimentally and corresponded to approximately three identities and one similarity for every five amino acids.

Next, the similarity between peptides and proteins related to the bovine $R$. (B.) microplus tick and deposited in the GenBank was investigated. Analysis was done by using the function "Search for Short Nearly Exact Matches" through the PAM30 matrix of the BLAST software program. Amino acids similar in four or more identical AA within a peptide sequence were determined as a similar motif of the corresponding protein sequences.

A search for similarity between peptides and predicted protein based on ESTs of the $R$. (B.) microplus was carried out in GenBank. For this we used the program BLAST defined as: "\$blastall -p tblastn -i peptides -d ests -e 100 -b 1 -F f -o result."

\section{Results}

The selected phage clones were sequenced, translated, and analyzed using bioinformatics, and generated 107 different peptides in a total of 281 sequences. Some selected phagotopes showed excellent matches with linear sequences of known proteins of $R$. (B.) microplus. Peptides that did not present significant matches with known proteins, but shared extensive homology among each other, were clustered and classified as conformational epitopes of $R$. (B.) microplus, or considered as phagotopes of non-proteic antigens.

A list of proteins classified in decreasing order of similarities to peptides was generated. Tables 1 and 2 present the $R$. (B.) microplus proteins described in GenBank, classified in accordance with the similarity to phagotopes. In Table 1, the subpopulations of selected peptides were divided in accordance with the seven selection strategies employed and were classified in decreasing order, with only the protein with the highest index of similarity for each selection strategy being represented. Table 2 shows only the 10 proteins having the highest indices of similarity. The proteins showing the highest matches in decreasing order were the precursor protein of GP80 putative secreted protein and the notch-like protein.

In Table 3, alignments were classified in decreasing order of frequencies of peptide phagotopes. The first column illustrates the ranking, in decreasing order, of proteins deposited in GenBank that contain motifs similar to the selected peptides. The third column represents the relation of the number of peptides similar to proteins (mimotopes) and the fourth column represents the number of alignments. A total of 66 different proteins referring to $R$. (B.) microplus were aligned. Three proteins con-
Table 1. Subpopulations of proteins aligned with the peptides were divided in accordance with seven adopted selection strategies and classified in decreasing order (FastaSkan).

\begin{tabular}{ccc}
\hline Selection & Score & Proteins (GenBank) \\
\hline S1 & 233.33 & BmTI-A \\
S2 & 178.57 & Cystatin \\
S3 & 259.26 & Serotonin receptor \\
S4 & 650.00 & Sodium channel \\
S5 & 470.00 & Carrapatin inhibiting protease \\
S6 & 666.67 & BM86 \\
S7 & 657.14 & GP80 precursor \\
\hline
\end{tabular}

Table 2. Alignments classified in decreasing order of frequencies of peptide phagotopes (FastaScan).

\begin{tabular}{ccc}
\hline Class & Score & Proteins (GeneBank) \\
\hline 1 & 107.92 & GP80 precursor \\
2 & 69.31 & putative secreted protein \\
3 & 50.50 & notch-like protein \\
4 & 47.52 & putative sodium channel \\
5 & 44.55 & leucokinin-like peptide receptor \\
6 & 44.55 & salivary gland metalloprotease \\
7 & 44.55 & yolk cathepsin \\
8 & 43.56 & G-protein coupled receptor \\
9 & 41.58 & cell surface glycoprotein BM86 \\
10 & 41.58 & glucose 6-phosphate dehydrogenase isoform C \\
\hline
\end{tabular}

Table 3. Alignments classified in decreasing order of frequencies of peptide phagotopes (BLAST).

\begin{tabular}{cccc}
\hline Number & Proteins & Frequence & Match \\
\hline 1 & Salivary gland metalloproteases & 28 & 35 \\
2 & Notch-like protein & 27 & 43 \\
3 & GP80 Precursor & 27 & 36 \\
4 & Esterase & 17 & 19 \\
5 & Membrane B antigen & 14 & 16 \\
6 & Calreticulin & 14 & 14 \\
7 & Sodium channel & 12 & 13 \\
8 & Reverse transcriptase-type protein & 11 & 12 \\
9 & P450 CYP319A1 & 11 & 12 \\
10 & Paramyosin & 11 & 11 \\
& Acetylcholinesterase & 10 & 12 \\
\hline
\end{tabular}

taining more protein motifs similar to peptides are highlighted, with the most frequent proteins being salivary gland metalloproteases, notch-like proteins, and GP80 precursor. The proteins showing the highest matches in decreasing order were the notch-like protein, the precursor protein of GP80 protein, and the salivary gland metalloproteases.

Table 4 shows only the eight peptides having the highest indices of similarity with the predicted proteins to $R$. (B.) microplus ESTs. The function of these proteins has not been identified yet. 


\section{Discussion}

This strategy was established to discriminate and reduce the number of clones, to be specific to the target. The stringent selection processes coupled with bioinformatics assays allowed us to narrow down the number of peptides that should be tested directly as immunogens and at the same time indicate the native antigens to be tested as new targets.

After the selection experiments, our preliminary results suggest that the epitope-displaying M13 phages could be used as immunogens to mapping new $R$. (B.) microplus antigens according to three findings. First, the peptide epitope sequences sharing the consensus sequence frequently correlate with many secreted proteins, indicating some of the most likely antigens directly involved. Second, alignment revealed similarities of motifs with several antigenic proteins and also the proteins having important cell functions. Third, the clones were shown to present high similarity with the tick GP80 precursor. A parallel experiment using antibody libraries from these same chickens and the scFv selected with the larval antigens could recognize a GP80 precursor that was determined by $\mathrm{N}$-terminal sequencing (SOUZA, 2007). Finally, taken together, the data strongly suggest the specificity of mapping possible native tick immunogens and it may be used to build a $R$. (B.) microplus epitope bank (epitome) in the future to select and construct a multi-epitope vaccine.

The results also indicate the potential of using this methodology as an alternative approach for finding and validating new proteins. This is specially useful for $R$. (B.) microplus, whose novel antigenic proteins are of great necessity for the control of this parasitism and for pointing new directions for the development of a successful vaccine. Thus, the possibility to develop new recombinant subunit vaccines produced by using biotechnology holds great promise for the future of veterinary vaccines that apply genomic tools as new data become available.

By using bioinformatics analysis methods, phage clones and $R$. (B.) microplus proteins were determined according to a sequence of linear amino acids, which are the constituent parts of these fusion peptides. Thus, we were able to demonstrate the antigenic profile of $R$. (B.) microplus by selecting phage display libraries. Our analyses revealed the potential of this methodology for the discovery of new vaccine candidates.

\section{Conclusion}

The present study demonstrates the feasibility of identifying important $R$. (B.) microplus phagotopes and native proteins for vaccine development through the screening of phage-displayed random peptide libraries and bioinformatics tools. Future work will be done to identify and characterize additional phagotopes, and to optimize the validation process for the best vaccination results.
Table 4. Representation of similarities between the recombinant peptides and proteins predicted to ESTs of Rhipicephalus (Boophilus) microplus deposited in GenBank.

\begin{tabular}{ccc}
\hline $\begin{array}{c}\text { Sequence } \\
\text { (Fago) }\end{array}$ & $\begin{array}{c}\text { Accession } \\
(\mathbf{G b})\end{array}$ & $\begin{array}{c}\text { Clone } \\
\text { (mRNA) }\end{array}$ \\
\hline Sequence ID No 4 & $\mid$ CV447142.1| & BEAFD73 \\
Sequence ID No 22 & $\mid$ CV442976.1| & BEAEP08 \\
Sequence ID No 24 & $\mid$ CV443271.1| & BEAEQ76 \\
Sequence ID No 42 & $\mid$ CK192020.1| & BEAD714 \\
Sequence ID No 75 & $\mid$ CV455770.1| & BEAGS85 \\
Sequence ID No 79 & $\mid$ CV445416.1| & BEAF345 \\
Sequence ID No 81 & $\mid$ CK185650.1| & BEAC593 \\
Sequence ID No 93 & $\mid$ CK183322.1 & BEABS50 \\
\hline
\end{tabular}

\section{Acknowledgements}

This work was supported by grants from Financiadora de Estudos e Projetos (FINEP), Vallée S/A, Coordenação de Aperfeiçoamento de Pessoal de Nível Superior (CAPES), Conselho Nacional de Desenvolvimento Científico e Tecnológico (CNPq) and Fundaçáo de Amparo à Pesquisa do Estado de Minas Gerais (FAPEMIG). The authors would like to thank the excellent assistance of Dra. Aline Aparecida Rezende Rodrigues and Dr. José Miguel Ortega for his valuable assistance for the in silico analyses.

\section{References}

BENHAR, I. Biotechnological applications of phage and cell display. Biotechnology advances, v. 19, n. 1, p. 1-33, 2001.

IRVING, M. B.; PAN, O.; SCOTT, J. K. Random-peptide libraries and antigen-fragment libraries for epitope mapping and the development of vaccines and diagnostics. Current Opinion in Chemical Biology, v. 5, n. 3, p. 314-324, 2001.

MANDAVA, S. et al. RELIC-a bioinformatics server for combinatorial peptide analysis and identification of protein-ligand interaction sites. Proteomics, v. 4, n. 5, p. 1439-1460, 2004.

SOUZA, G. R. L. Construçáo de uma biblioteca de anticorpos (scFv) apresentada em fagos para seleçáo, análise e caracterizaçáo de antígenos do carrapato bovino (Boophilus microplus). Uberlândia, 2007. 83f. Tese (Doutorado) - Instituto de Genética e Bioquímica, Universidade Federal de Uberlândia.

WANG, Y. S. et al. Development of a multi-mimotope peptide as a vaccine immunogen for infectious bursal disease virus. Vaccine, v. 25, n. 22, p. 4447-4455, 2007. 